\title{
Failure Analysis of Polymer Electrolyte Fuel Cells
}

\author{
Pratap Rama, Rui Chen and John Andrews
}

Loughborough University

Reprinted From: Fuel Cell Vehicle Applications, 2008

(SP-2167)

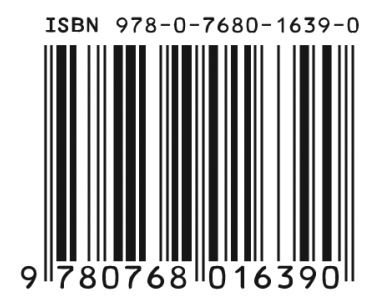


By mandate of the Engineering Meetings Board, this paper has been approved for SAE publication upon completion of a peer review process by a minimum of three (3) industry experts under the supervision of the session organizer.

All rights reserved. No part of this publication may be reproduced, stored in a retrieval system, or transmitted, in any form or by any means, electronic, mechanical, photocopying, recording, or otherwise, without the prior written permission of SAE.

For permission and licensing requests contact:

SAE Permissions
400 Commonwealth Drive
Warrendale, PA 15096-0001-USA
Email: permissions@sae.org
Tel: $\quad 724-772-4028$
Fax: $\quad 724-776-3036$

Fax: $\quad 724-776-3036$

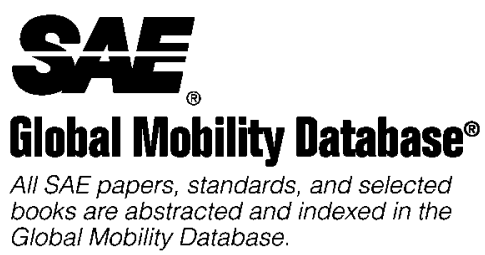

For multiple print copies contact:

SAE Customer Service

Tel: $\quad$ 877-606-7323 (inside USA and Canada)

Tel: $\quad$ 724-776-4970 (outside USA)

Fax: $\quad$ 724-776-0790

Email: CustomerService@sae.org

\section{ISSN 0148-7191}

\section{Copyright $\odot 2008$ SAE International}

Positions and opinions advanced in this paper are those of the author(s) and not necessarily those of SAE. The author is solely responsible for the content of the paper. A process is available by which discussions will be printed with the paper if it is published in SAE Transactions.

Persons wishing to submit papers to be considered for presentation or publication by SAE should send the manuscript or a 300 word abstract of a proposed manuscript to: Secretary, Engineering Meetings Board, SAE.

\section{Printed in USA}




\title{
Failure Analysis of Polymer Electrolyte Fuel Cells
}

\author{
Pratap Rama, Rui Chen and John Andrews \\ Loughborough University
}

Copyright @ 2008 SAE International

\begin{abstract}
A qualitative FMEA study of Polymer Electrolyte Fuel Cell (PEFC) technology is established and presented in the current work through a literature survey of mechanisms that govern performance degradation and failure. The literature findings are translated into Fault Tree (FT) diagrams that depict how basic events can develop into performance degradation or failure in the context of the following top events; (1) activation losses; (2) mass transportation losses; (3) Ohmic losses; (4) efficiency losses and (5) catastrophic cell failure. Twenty-two identified faults and forty-seven frequent causes are translated into fifty-two basic events and a system of FTs with twenty-one reoccurring dominant mechanisms. The four most dominant mechanisms discussed that currently curtail sustained fuel cell performance relate to membrane durability, liquid water formation, flow-field design, and manufacturing practices.
\end{abstract}

\section{INTRODUCTION}

PEFC technology has been the focus of research and development for over five decades. The technology inherently mitigates the need to combust reactant gases directly, which prevents the energy conversion device from being restricted to the Carnot efficiency. The fundamental processes of hydrogen-oxidation and oxygen-reduction results in water as the product, eliminating vehicular carbon, NOx and particulate matter emissions. As the cost per kW of PEFC technology approaches USD35 $/ \mathrm{kW}$, it is conceivable that the technology can become cost-competitive with conventional ICE technologies.

Automotive fuel cells are expected to operate under load-following or load-levelled modes and expected to withstand variations in environmental conditions, particularly in the context of temperature and atmospheric composition. Additionally, fuel cell powerplants are expected to survive under these conditions over the duration of their expected operational lifetimes i.e., around 5,500 hrs, while undergoing as many as 30,000 startup/shutdown cycles. The challenge for modern-day fuel cell research and development for automotive propulsion is to ensure that the technology is shaped for the delivery of safe, reliable and apt performance over its expected lifetime, whilst maintaining a level of transparency in the financial risk implied on those investing in fuel cell technology at both pre- and post- commercialization phases.

The continual drive to bring PEFC technology closer towards maturity is resulting in a vast multitude of materials, designs, manufacturing processes and considerations for the different components of a cell $[1,2,3]$. This reflects the fact that there are a multitude of factors that govern the performance of the cell, all of which are related to some element of physical design or operational practice that can be altered to improve an aspect of cell performance. The current work aims to provide a structured insight into the factors that govern the reliability and safety of PEFCs by considering the cause and effect of the underlying phenomenological processes.

In the context of fuel cells, failure can occur as a consequence of gradual processes; certain operating conditions and operational routines can cause a systematic degradation of structural and electrokinetic properties of PEFC assemblies and culminate in the irreversible loss of performance below critical thresholds. PEFCs are generally susceptible to multiple modes of performance loss; five top events are considered in the current study which reflect either performance degradation or failure:

(1) activation losses

(2) mass transportation losses

(3) Ohmic losses

(4) fuel efficiency losses

(5) catastrophic cell failure

This study forms part of a larger failure analysis which incorporates Failure Modes, Effects Analysis (FMEA) $[4,5]$. FMEA is a structured, qualitative and quantitative analysis of a system aimed at facilitating the identification of potential system failures modes, their causes and the effects on the system operation. The general procedure of FMEA is to consider each potential failure mode and to determine its effect on the system. The overall objective of the analysis is to identify reliability and 
criticality elements of a system to determine where modifications may be required to the system design or operating methodology, or where certain established competencies in fuel cell design and operation should prevail. The first part of the study is presented here, where through a literature survey, the different degradation mechanisms that induce potentially irreversible performance losses in the context of the five loss mechanisms are understood and mapped into diagrammatic form via FTs [6]. An FT is a top-down representation of the state of a system (top event) in terms of the state of its components (basic events).

\section{PERFORMANCE DEGRADATION AND FAILURE ANALYSIS}

\section{LOSS MECHANISMS}

Activation Losses - Activation losses are attributed to the slowness of reactions occurring in the fuel cell electrodes. The anode kinetics are much faster than the cathode kinetics. Activation losses can increase during the course of cell operation if the electrochemically active surface area (EASA) reduces in the fuel cell catalyst layers. The most prominent mechanisms that induce performance degradation through activation losses are as follows;

- agglomeration and/or ripening of platinum particles: subjecting PEFCs to repetitive on/off load cycles induces a susceptibility to platinum sintering. Sintering results in a loss of EASA.

- platinum migration: when the PEFC is operated through hydrogen-air open circuit to air-air open circuit, platinum can become soluble and liable to transportation through adjacent layers. Loss of catalyst results in a loss of EASA

- exposure to sub-zero operating conditions: the repetitive freezing and melting of water residing within the catalyst layer is likely to deform the structure of the catalyst layers by increasing the pore size and reducing the EASA

- atmospheric contaminants: air impurities such as $\mathrm{NO}_{2}, \mathrm{SO}_{2}$ and $\mathrm{H}_{2} \mathrm{~S}$ have a negative impact on cell performance due to their adsorption on platinum catalyst sites. Cyclic voltammetry can be applied to recover the cathodic EASA for contaminant concentrations less than $5 \mathrm{ppm}$.

- fuel contaminants: operating PEFCs on hydrocarbon reformate yields a susceptibility of exposing the anode catalyst layer to $\mathrm{CO}$ in the concentration range of $10-100 \mathrm{ppm}$. CO adsorbs onto Pt more strongly than $\mathrm{H}_{2}$ which thereby compromises the EASA for hydrogen oxidation. Additional $\mathrm{CO}$ can form through reverse water-gas shift reactions or through the electro-reduction of $\mathrm{CO}_{2} \quad\left(\mathrm{CH}_{4}\right.$ reformation typically yields an $80 / 20$ hydrogen/ $/ \mathrm{CO}_{2}$ stream with $\mathrm{CO}$ in the mentioned concentrations). $\mathrm{CO}$ can also affect the cathode catalyst layer through crossover.

- carbon corrosion: if a single cell has insufficient fuel to support the current drawn, carbon in the catalyst layer as catalytic support can corrode to supply protons to support the current above that provided by the fuel. This compromises the stability of the catalyst layer and the EASA in the anode. Platinum agglomeration can be instigated through carbon corrosion.

- chemical degradation of chemical seals: seals in fuel cell stacks are made of silicone and serve to avoid the mixing of hydrogen and oxygen. The acidic nature of the polymer electrolyte membrane and the thermal stresses applied to the silicone seal can cause it to chemically degrade. The decomposition products react with catalysts to form particles containing silicone, oxygen and platinum. This therefore also compromises the EASA.

Mass Transportation Losses - these losses occur when there is a disparity between the rate at which reactant are supplied and the rate at which they are consumed. The disparity is induced by an impedance to the supply of reactants to the catalyst sites and can be instigated by a number of processes;

- cell flooding: the formation of liquid water in the cathode, restricting the transport of oxygen

- loss of hydrophobic material: porous fuel cell layers such as the gas diffusion layer (GDL) are often treated with hydrophobic polytetrafluoroethylene (PTFE) to facilitate liquid water removal. The PTFE is susceptible to mechanical and electrochemical degradation particularly when subjected to thermal cycles, which can subsequently cause the rate of liquid water accumulation to increase

- excessive ionomer loading in the catalyst layer: limited control during fabrication can result in excessive ionomer loading or the formation of ionomer skins on catalyst sites, impeding reactant transport

- ice formation: residual water in a single cell can freeze and remain in a solid state during subsequent start-up and short periods of operation. This too impedes the transport of reactant gases

- over-compaction: over-tightening during stack construction can cause pores to collapse in the GDL. This has the effect of reducing the overall porosity and the pore connectivity, resulting in a loss in permeability

Ohmic Losses - both the resistance to proton transport and electron transport in respective ion-conducting cell materials contribute towards Ohmic losses. Resistance to electron transfer is largely attributed to the bipolar plate (BPP) material;

- $\quad$ stainless-steel (SS) BPP: passivating layers such as $\mathrm{Cr}_{2} \mathrm{O}_{3}$ are developed on the surface of stainless steel for corrosion resistance. These thin films, however, possess high interfacial contact resistances (ICR), the magnitude of which depends upon the $\mathrm{Cr}$ and $\mathrm{Ni}$ content of the SS 
- SS substrate coating: SS can be coated with conductive polymers for corrosion resistance while maintaining low ICRs. Loss of coating and subsequent surface corrosion can lead to high ICRs compared to pristine SS

- Inhomogeneously-mixed polymer-carbon BPPs: injection-moulded BPPs can suffer from polymer-rich boundaries during the moulding process, particularly if the material is not homogeneously mixed prior to injection. This results in compromised electron conductivity close towards the surface

Resistance to proton transfer is attributed to the polymer electrolyte material;

- dehydration: protons are transferred through the polymer electrolyte membrane via a Grotthus hopping mechanism, which fundamentally depends upon the presence of water. As such, by ensuring that the membrane is kept well hydrated the proton conductivity can be maintained and Ohmic losses can be minimised. Inadequate water management can lead to dehydration and resistance to proton transfer. Membrane dehydration can be induced by the following two mechanisms;

- impurity ion penetration in the polymer electrolyte membrane: impurity ions penetrating through to within the polymer electrolyte membrane can reduce the diffusion coefficient of water in the membrane and can increase the water transfer coefficient. This prevents water from being uniformly distributed through the membrane and raises Ohmic losses. Sources of impurity ions include impure reactant gas feeds, corroded materials in the fuel cell stack or reactant supply system, fittings, tubing or ions in the water or coolant supply

- anisotropic expansion: it is permissible that when the polymer electrolyte membrane swells anisotropically due to water uptake, the local through-plane conductivity can decay as diffusion pathways in the membrane are forced to collapse.

Efficiency Losses and Catastrophic Cell Failure - Loss of efficiency and catastrophic cell failure can be induced when the strength and stability of fuel cell materials are degraded irreversibly by mechanical or chemical attack.

- Mechanical attack: thermal hotspots can form in regions of the cell for example at the beginning of rib areas where current enters the GDL from the BPP, regions where there are high reaction rates or spots of high compression. Other factors include manufacturing defects that give rise to irregularities in the electrolyte membrane. Thermal hotspots result in the electrolyte membrane failing mechanically and the formation of pinholes. Other factors include environmentally-induced vibration which can induce fractures in rigid elements such as the BPP.

- Chemical attack: susceptibility to chemical attack of polymer electrolyte membrane can occur due to the presence of defects in the polymer groups. End groups can interact with active radicals, resulting in the chemical degeneration of the membrane.

\section{FAILURE ANALYSIS SUMMARY}

Table $1 \mathrm{a}$ and $1 \mathrm{~b}$ summarises the full list of failure modes and causes compiled from the literature. Twenty-two faults are recognised which expand into forty-seven potential causes.

\section{FAULT TREE ANALYSIS}

As indicated in Tables $1 \mathrm{a}$ and $1 \mathrm{~b}$, the top events in the context of fuel cell performance degradation and failure reflect the five mechanisms listed in the introduction. The processes described in Table 1 subsequently allow the construction of a system of FT diagrams including five main diagrams for the top events and twenty-one transfer events.

The transfer events reflect self-contained, reoccurring mechanisms that can contribute towards inducing other mechanisms and which ultimately lead on to performance degradation or cell failure. Figures 1 to 5 illustrate the five top events. The FT diagrams for all of the transfer events are not illustrated here, but summarised in Table 2. As an example, however, transfer event 20 - loss in dynamic pressure in BPP channels - is given in Figure 6. A description of all the basic events in the system of fault trees is given in the appendix. Here, the four most frequent transfer events are discussed, in descending order of frequency in the complete system of FT diagrams.

Uptake of Water - Table 2 reveals that the uptake of water in the ionomer membrane is the most commonly occurring process in all the events that lead to the five top events. Water uptake is an inherently occurring process that permits the mobility of protons from anode to cathode, however, it is evident that its occurrence is also conducive of events that contribute towards the four loss mechanisms and catastrophic cell failure. Water uptake can cause the membrane to swell anisotropically, depending upon local fluid-dynamic properties of the reactant gases passing either side of each cell and therefore the local current density as well. For the regions where swelling is most extensive, the expansion of the ionomer can cause the interfacial contact forces between layers to increase, thereby resulting in localised spots of high compaction. These regions can become thermal hotspots, where subsequent punctures in the membrane are likely to develop. The ensuing pinhole formation leads on to efficiency losses or indeed catastrophic cell failure. Simply the repeated swelling and contraction of the membrane due to the water uptake cycles can precipitate membrane puncture. 


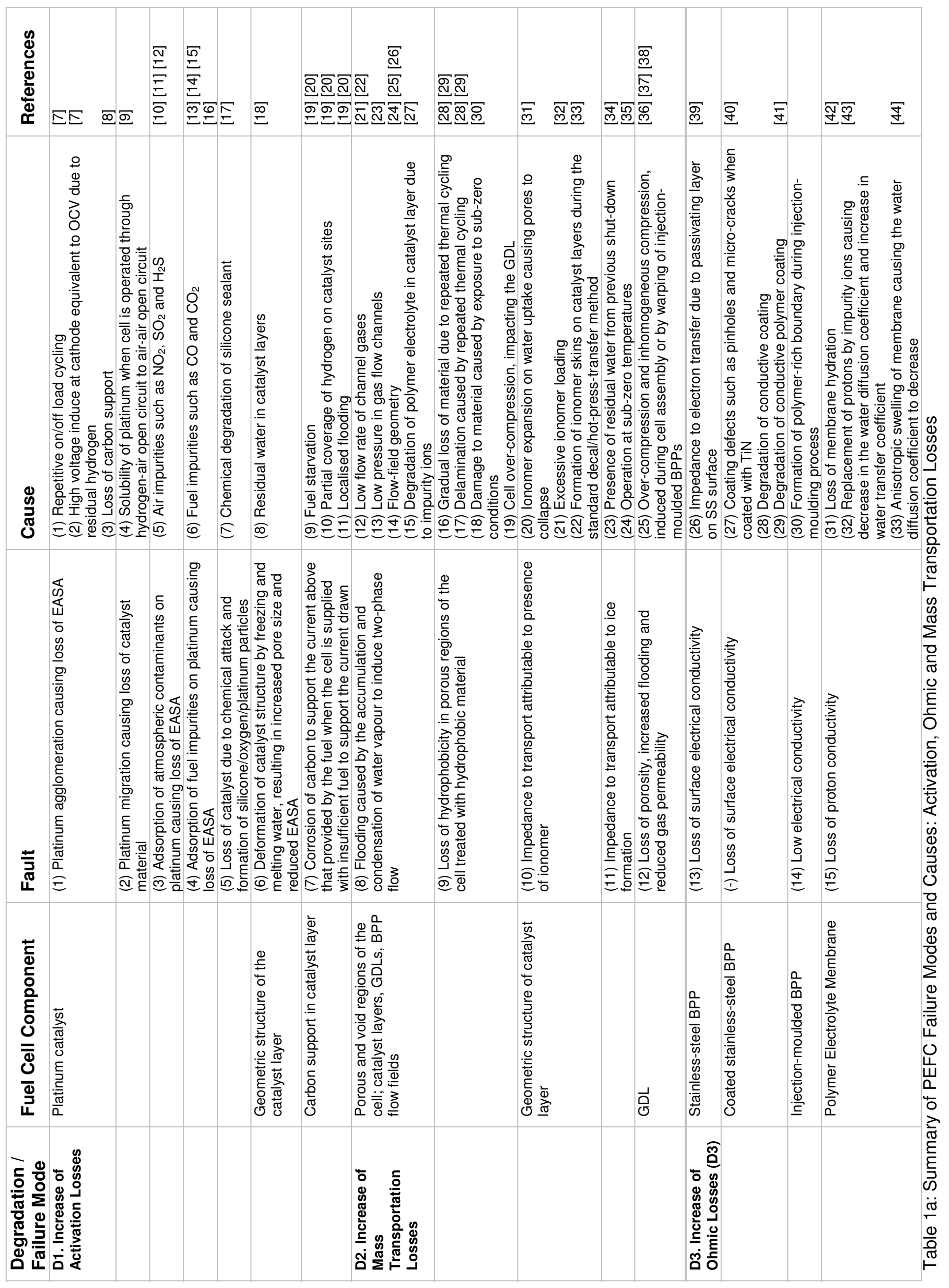




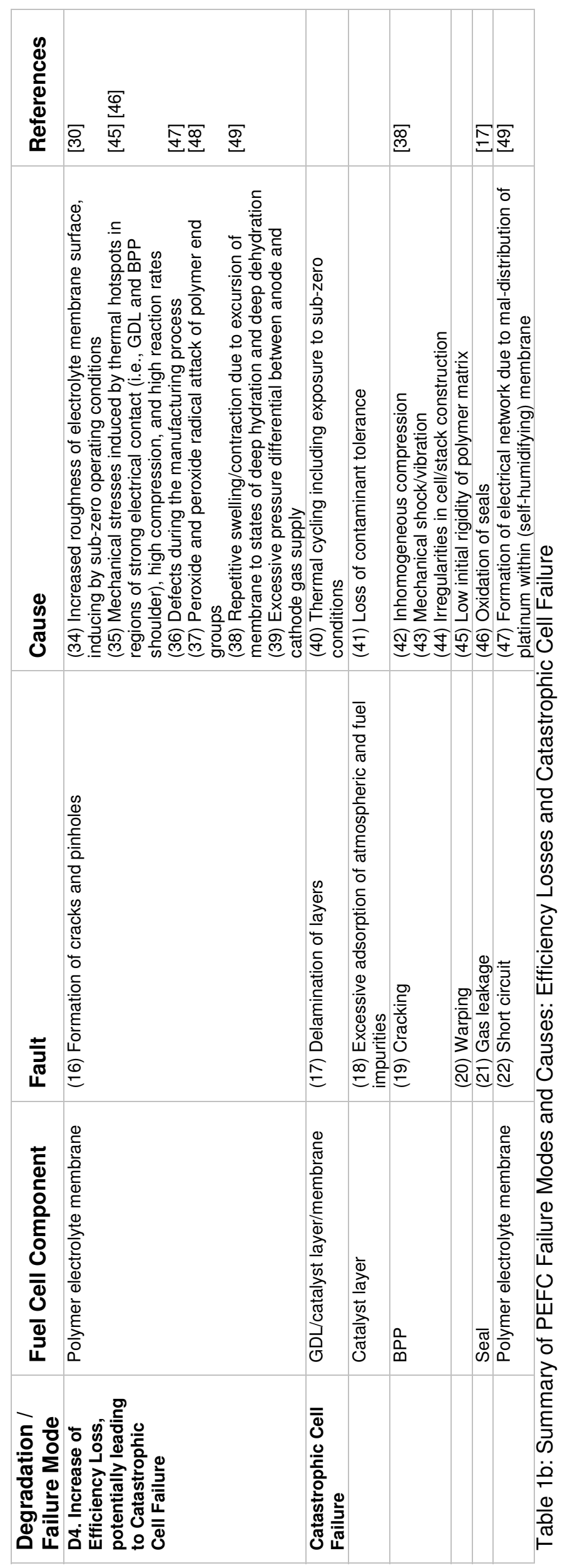




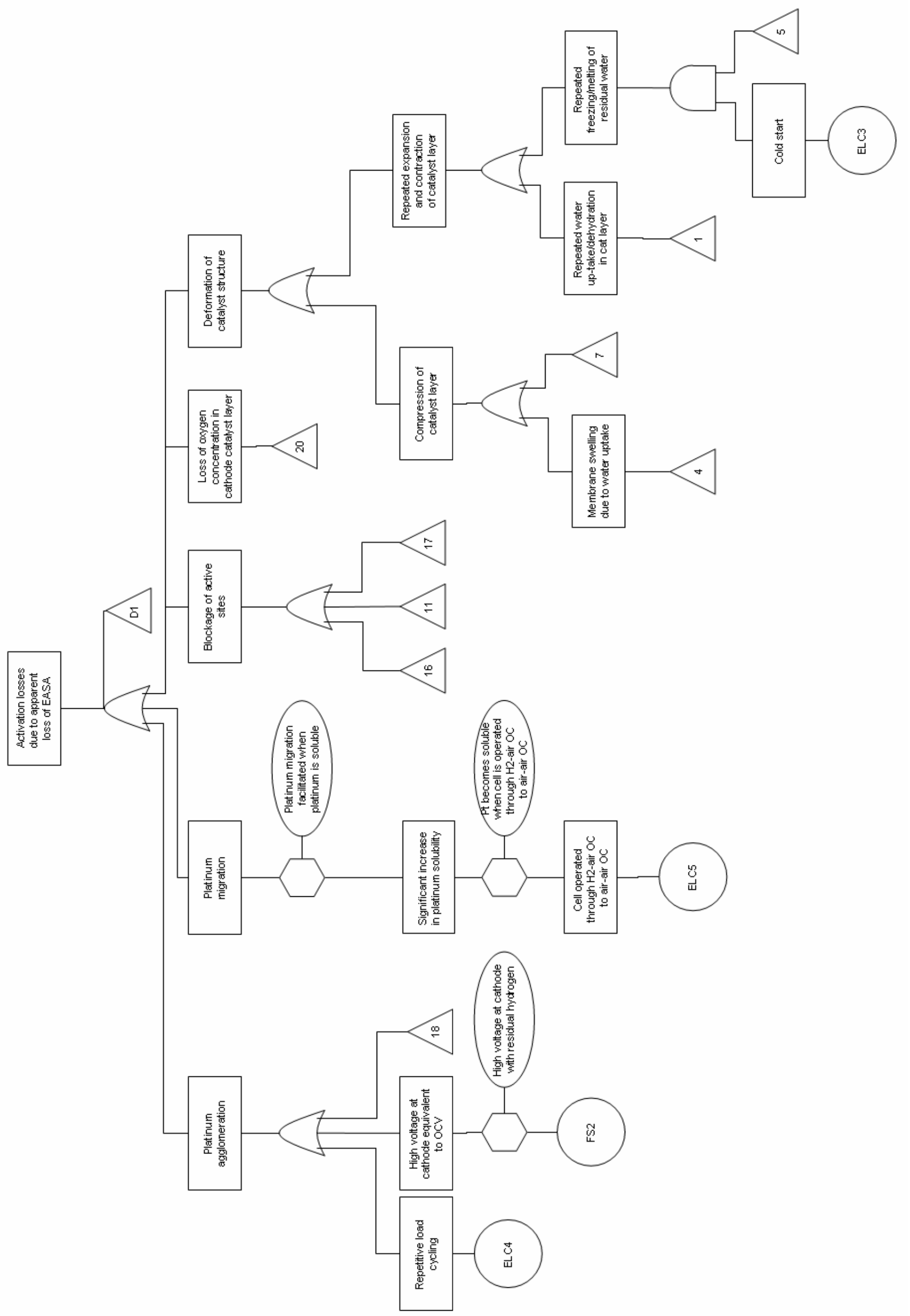

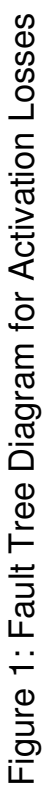




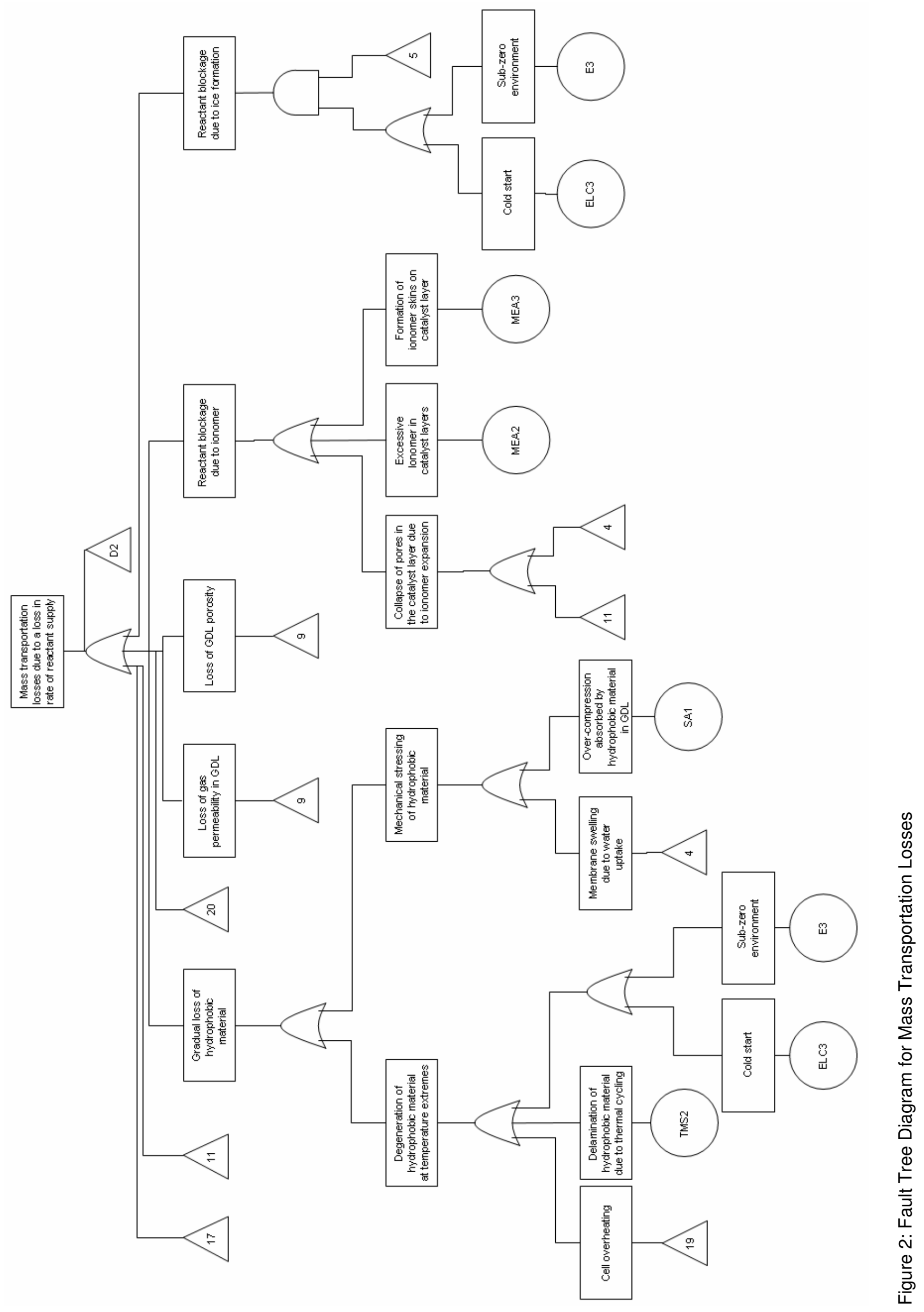




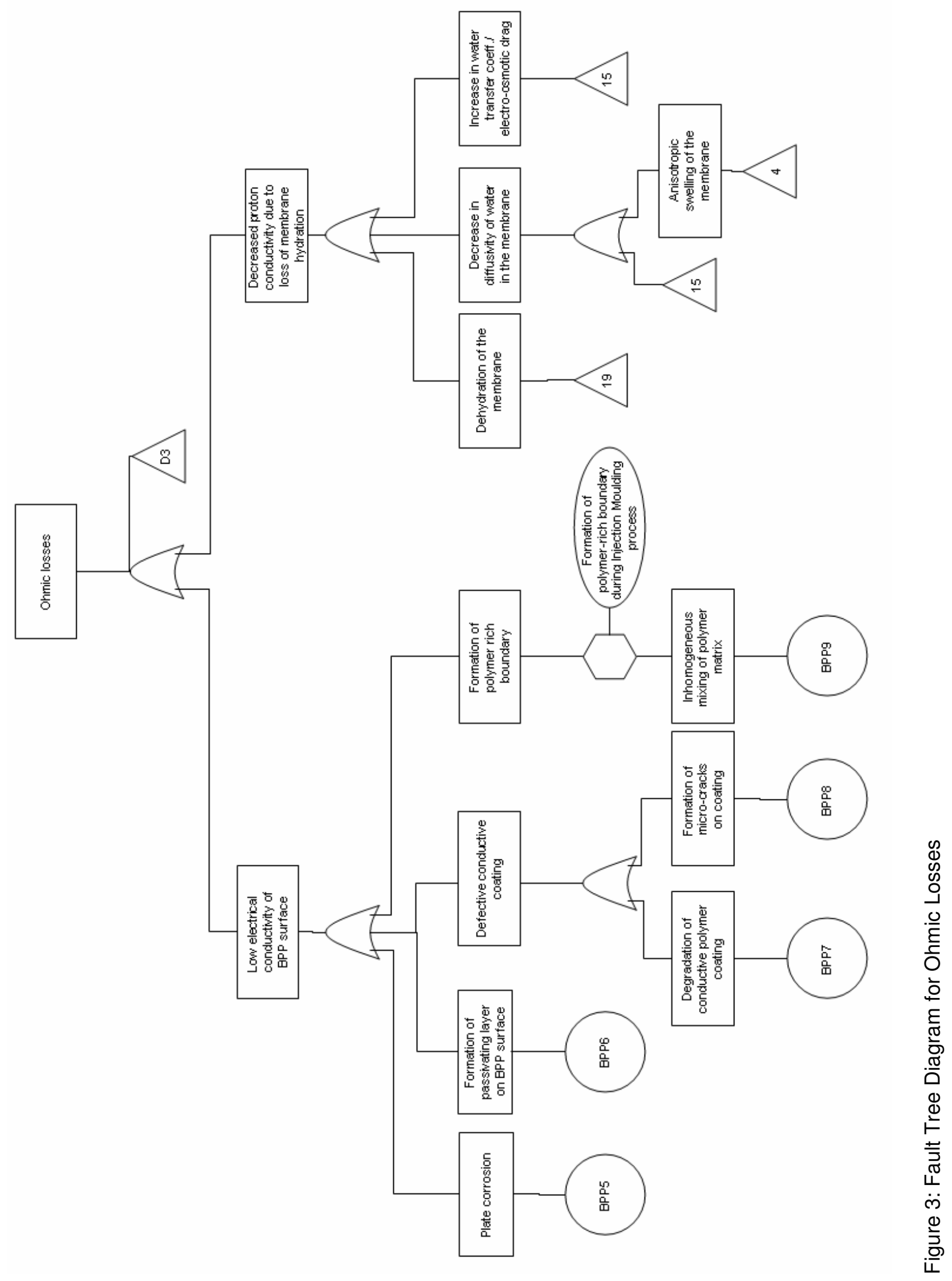




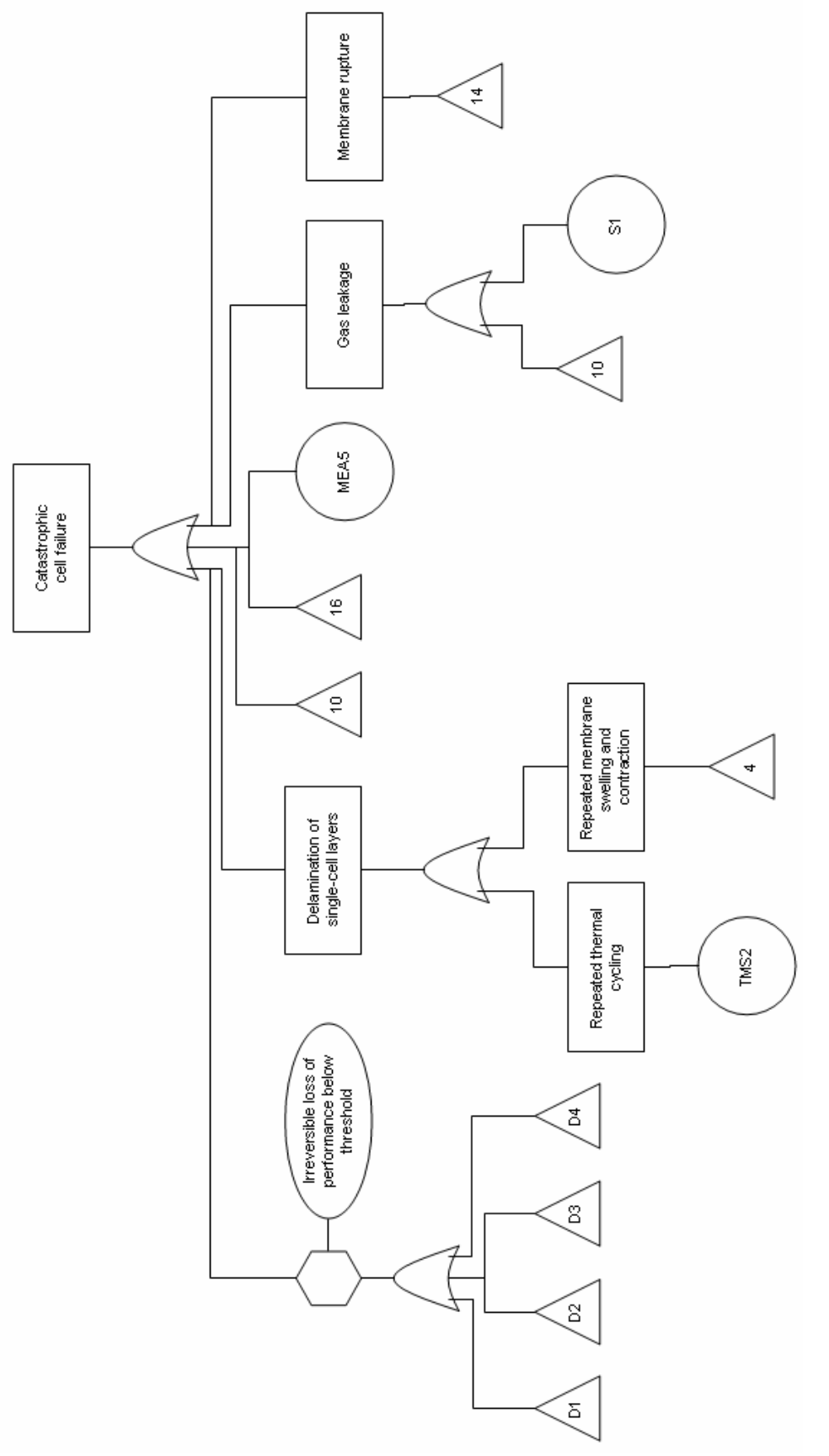

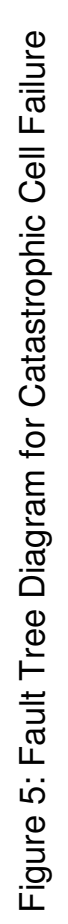

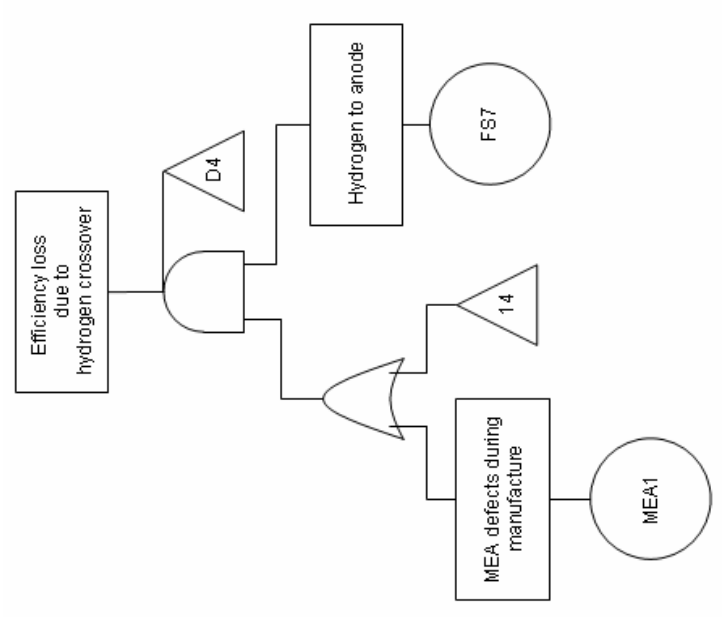

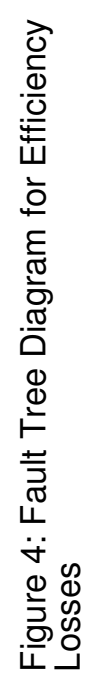




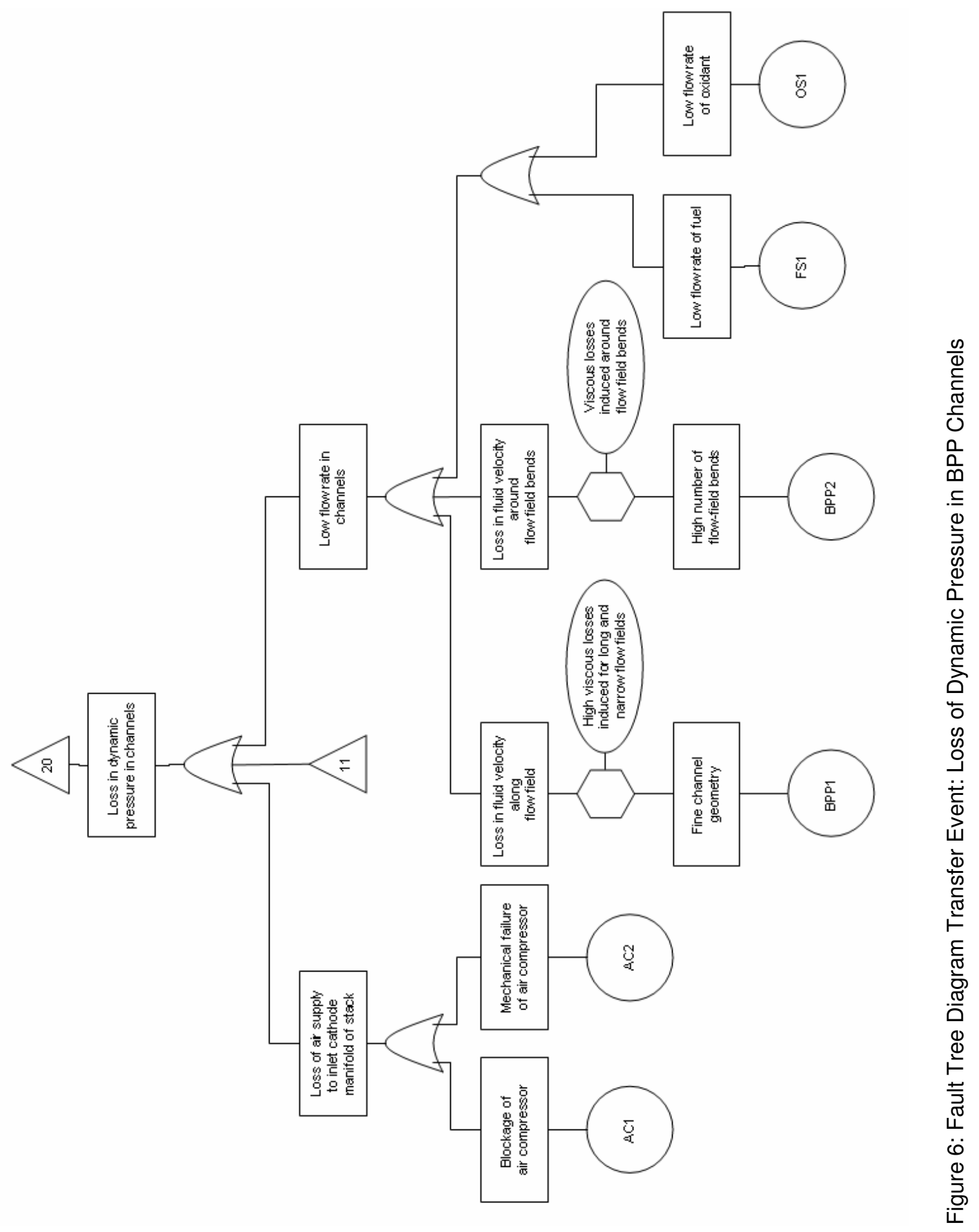




\begin{tabular}{|c|c|c|c|c|c|c|}
\hline \multirow[t]{2}{*}{ Event } & \multirow[t]{2}{*}{ Frequency } & \multicolumn{5}{|c|}{ Top Events Affected } \\
\hline & & $\mathrm{OL}$ & $\mathbf{A L}$ & MTL & EL & CCF \\
\hline $\begin{array}{l}\text { 4. Uptake of water in } \\
\text { the ionomer } \\
\text { membrane }\end{array}$ & 10 & $x$ & $x$ & $x$ & & $\mathrm{X}$ \\
\hline $\begin{array}{l}\text { 20. Loss in dynamic } \\
\text { pressure in channels }\end{array}$ & 5 & $x$ & $\mathrm{X}$ & $\mathrm{X}$ & & \\
\hline $\begin{array}{l}\text { 3. Liquid water } \\
\text { accumulation }\end{array}$ & 4 & $x$ & $\mathrm{X}$ & $x$ & & $x$ \\
\hline $\begin{array}{l}\text { 7. Over-compression } \\
\text { during stack } \\
\text { assembly }\end{array}$ & 4 & & $\mathrm{x}$ & & & $x$ \\
\hline $\begin{array}{l}\text { 1. Water production at } \\
\text { the cathode }\end{array}$ & 3 & $x$ & $\mathrm{X}$ & $x$ & & $\mathrm{X}$ \\
\hline $\begin{array}{l}\text { 9. Collapse of GDL } \\
\text { pores }\end{array}$ & 3 & & $\mathrm{X}$ & $\mathrm{X}$ & & \\
\hline 11. Cathode flooding & 3 & & $X$ & $X$ & & \\
\hline $\begin{array}{l}\text { 13. Penetration of } \\
\text { impurity ions }\end{array}$ & 3 & $x$ & & & $x$ & $x$ \\
\hline 5. Residual water & 2 & & $X$ & $X$ & & \\
\hline $\begin{array}{l}\text { 6. Increase in internal } \\
\text { compaction force }\end{array}$ & 2 & & & & $x$ & $x$ \\
\hline $\begin{array}{l}\text { 8. High compression } \\
\text { between GDL fibre } \\
\text { and MEA }\end{array}$ & 2 & & & & $x$ & $x$ \\
\hline 10. Cracking of BPP & 2 & & & & & $\mathrm{X}$ \\
\hline $\begin{array}{l}\text { 12. Formation of } \\
\text { hydrogen peroxide }\end{array}$ & 2 & & & & $x$ & $x$ \\
\hline 14. Pinhole formation & 2 & & & & $X$ & $\mathrm{X}$ \\
\hline $\begin{array}{l}\text { 15. Replacement of } \\
\text { protons in the } \\
\text { membrane by impurity } \\
\text { ions }\end{array}$ & 2 & $X$ & & & & \\
\hline $\begin{array}{l}\text { 16. Adsorption of } \\
\text { impurities on active } \\
\text { sites }\end{array}$ & 2 & & $X$ & & & $x$ \\
\hline $\begin{array}{l}\text { 17. Formation of } \\
\text { silicone/oxygen/platin } \\
\text { um particles }\end{array}$ & 2 & & $x$ & $x$ & & \\
\hline $\begin{array}{l}\text { 19. Inadequate heat } \\
\text { removal }\end{array}$ & 2 & $X$ & & $x$ & & \\
\hline $\begin{array}{l}\text { 21. Inhomogeneous } \\
\text { compression }\end{array}$ & 2 & & $\mathrm{X}$ & $\mathrm{X}$ & & $x$ \\
\hline $\begin{array}{l}\text { 2. Liquid water } \\
\text { formation }\end{array}$ & 1 & $x$ & $x$ & $x$ & & $x$ \\
\hline $\begin{array}{l}\text { 18. Loss of carbon } \\
\text { support }\end{array}$ & 1 & & $x$ & & & \\
\hline
\end{tabular}

Table 2: FT Transfer Events; frequency and top events affected

This mechanism of repeated swelling and contraction induces a number of other significant processes. The process can also cause a repeated compression of the catalyst layer, eventually resulting in the deformation of the catalyst layer structure which reduces the EASA and thereby results in the increase of activation losses. It also affects mass transportation losses, as evident in Figure 2. First, the swelling and contraction causes the hydrophobic material in the GDL to become mechanically stressed, causing it to erode. This then compromises the removal of liquid water, and therefore hastens the onset of cell flooding. Second, Figure 2 shows that if the ionomer membrane in the catalyst layer expands on water uptake, the pores and pore networks in the catalyst layer are likely to collapse, again, inducing an impedance to reactant transport through a decrease in porosity and permeability respectively. Swelling and contraction can also eventually precipitate catastrophic cell failure by causing the layers of a single cell to delaminate. Water uptake also facilitates the transport of impurity ions through a leaching mechanism. This then promulgates towards increased Ohmic losses either by decreasing the diffusivity of water or by increasing the electroosmotic drag in the ionomer membrane.

Pressure Losses in BPP Flow Fields- Table 2 reveals that channel pressure losses can induce ohmic, activation or mass transportation losses. Ohmic losses can be hastened if low pressure in the channels prevents liquid water to be removed by advection or convection, such that leached impurities remain within the cell with the liquid water. Carbon corrosion can occur in the presence of excess liquid water, which can thereby hasten platinum agglomeration and cause an eventual increase in activation losses. Pressure drops are coupled to a drop in reactant mass flow rate. If viscous forces in the flow fields induce pressure losses, the rate at which reactants are supplied also correspondingly drop, thereby inducing mass transportation losses, as evident in Figure 2. At the same time, since the partial pressure and therefore the concentration of oxygen in the cathode catalyst layer will drop, activation losses will increase.

Liquid Water Accumulation - The accumulation of liquid water is also a critical process. Predominantly, it leads on to cathode flooding which raises mass transportation losses and can also cause the pressure to drop in the reactant supply channels. Liquid water accumulation in the cathode catalyst layer also forces a decrease in the local concentration of oxygen, thereby inducing an increase in activation losses. Active sites in the catalyst layer become covered by films of liquid water, creating a barrier through which oxygen would have to diffuse. The degree of inaccessibility would increase with the degree of flooding in the catalyst layer. Since the uptake of water in the ionomer regions is augmented when equilibrated by liquid water [47], it is correspondingly coupled to the mechanisms already discussed.

Over-compression - Over-compression in a stack is also evidently a significant issue. It impacts the activation losses because it can cause a deformation of the catalyst layer structure, reducing the EASA as shown in Figure 1. Critically, however, it can induce catastrophic cell failure through different mechanisms. First of all, over-compression can cause bipolar plates to crack, which can also lead on to reactant leakage. In addition, it is possible to trace over-compression as a phenomenon that can also hasten the formation of thermal hotspots and punctures, as discussed.

\section{DISCUSSIONS}

The results from Table 2 provide an insight into where there is necessity to favourably reform some elements of fuel cell design, manufacturing and operational practices with the aim of retarding performance degradation and failure. These are discussed herein.

Membrane Mechanical Strength and Dimensional Stability - It is evident that the dimensional stability and the mechanical strength of the membrane are key 
attributes which if improved can extend fuel cell survivability by curtailing the effects of repeated membrane swelling and contraction, and indeed by improving resistance to the formation of pinholes and punctures.

Water uptake is intrinsic to the way in which the membrane operates, but it is the effects of its expansion which can be problematic. The adjacent fuel cell layers have to absorb the expansion and thereby undergo further localised compaction which can compromise their internal structures with time. Adverse effects are also apparent at the layer interfaces, which repeatedly transmit the forces due to expansion and also become regions that are mechanical weak with respect to time. Layers are likely to delaminate from one another and hydrophobic coatings are likely to degenerate. The mechanical strength can dictate the susceptibility to pinhole formation, especially in regions of thermal hotspots and especially for thin membranes purposely employed for improved and more uniform hydration.

Membrane expansion could be restrained by the compaction of the cell. However, it has already been argued that the stresses actually experienced in operating fuel cells are likely to be less than those required to sufficiently constrain the membrane [50]. Reinforcing the membrane structurally however could provide a more robust method. Some methods recently explored in the literature include dispersing PTFE fibrils within membranes (fibril content of 2.7 wt.\%), termed Flemion Rf2 membranes [51], dispersing carbon nanotubes within Nafion membranes (CNT content of 1 wt.\%) [52] and the use of porous, expanded PTFE (ePTFE) sheets that are bonded with membrane resins on both sides $[53,54,55]$.

It is arguable that the mechanical properties of conventional membranes become key issues because of the large fraction to which they absorb water [56]. Therefore, if the dependence upon the uptake of water and its subsequent interaction with end groups to produce proton conductivity can be mitigated then membrane durability can ultimately be extended. One possible way is by modifying existing membranes to enable self-humidification and another is through radical re-engineering of polymer systems.

Maintaining Vapor-Phase Water - Through the fault tree analysis it is possible to identify that liquid water accumulation can induce mechanisms that increase ohmic losses, mass transportation losses, activation losses and can indeed catastrophic cell failure. The formation of liquid water is in part permitted by operating at low temperatures, i.e., $80^{\circ} \mathrm{C}$ or below. The saturation vapour pressure at these temperatures is below $0.5 \mathrm{~atm}$, which means that the relative humidity of the reactant gases can quickly reach and exceed unity, particularly if they are already supplied close to full humidification. This is especially true for the cathode side where water is produced. When the reactant gases become oversaturated, the vapour-phase water undergoes a phase change through condensation to form liquid water.
Condensation causes a release of latent heat and the resulting liquid-phase limits the amount of heat energy that can be removed from the cell in the form of sensible heat. This commands the use of complex thermal management systems to maintain the operating temperature. Operating above $100^{\circ} \mathrm{C}$, however, raises the saturation vapour pressure, enhancing the capacity to which reactant gases can hold high concentrations of water in vapour phase, which thereby delays the onset of liquid water formation and cell flooding. In addition, since water remains in the vapour phase, the latent heat is retained and more heat energy can be removed from the cell in the form of sensible heat, i.e., through steam. Operating at higher temperatures commands the development of higher temperature membrane technology, including corresponding screening and diagnostics capabilities.

Flow-Field Design - It has long been known that flow field design alone can strongly dictate the performance of the fuel cell. The flow field design essentially governs the uniformity to which reactant gases are supplied over the active cell area and the extent to which continuous pathways can be maintained for the removal of unspent gases, unimpeded by liquid water. As such, it is evident that the performance of the cell can be improved by optimizing the fluid dynamics of the flow within the flow fields independently of MEA development. This area has therefore already received much attention and resulted in various patents [57]. There are generally two dominant flow field configurations, namely parallel and serpentine. These configurations can be applied in the form of single or multiple channels and the flow fields can indeed be either continuous or interdigitated (discontinuous).

In the general case, pressure losses along single channels can be minimised if the overall flow field path length is kept short and if the number and abruptness of bends are minimised. Indeed recent studies have highlighted that uniform flows with typically small pressure drops can be established particularly for flow fields with straight, parallel channels [58] and for serpentine channels that have shorter path lengths and larger numbers of multiple channels rather than longer path lengths and fewer channels within the same cell area [59]. Such measures can ensure that the channels remain pressurised along their entire lengths and reduce the chance of flooding whereby high upstream pressures and low downstream pressures are established causing liquid water to be pushed down and accumulate in downstream regions of the flow fields [60]. Liquid water can inevitably accumulate in any region where the gasphase flow becomes stagnant, particularly in abrupt $180^{\circ}$ bends often seen for serpentine flow fields $[61,62,63]$.

The optimization of the flow field, however, must be conducted without neglecting the properties of the GDL. In effect, both of these materials serve similar purposes from a mass transportation perspective in terms of ensuring that the active area of the MEA is persistently covered by reactant gases, and in terms of ensuring that unspent gases and excess water are constantly removed. The flow field geometry in effect therefore has 
to be matched with the porosity and the permeability of the GDL $[64,65]$.

Manufacturing and Quality Control - Manufacture and quality control intrinsically dictate the performance, reliability and safety of fuel cells and fuel cell stacks. At present, fuel cell manufacturing comprises of several discrete low-volume processes primarily based on scaled-up laboratory fabrication methods and heavy reliance on manual intervention, particularly for overall stack assembly [66]. Many of the mechanisms detailed in the fault tree diagrams are induced because of these current practices, for example, excessive ionomer loading in the catalyst layers and over-compression during stack assembly. Fuel cell manufacturing should incorporate processes capable of supporting highlyautomated high-volume, low-cost manufacture which ensure repeatability with accuracy in the context of exacting dimensions. At present, the entire area of fuel cell technology development is still very much in a fluid state, and many of the current low-volume manufacturing processes employed reflect this. It is possible, however, to foresee that some of the susceptibilities to degradation and failure that are introduced to fuel cells via manufacturing could be minimised or eradicated altogether by progressively applying manufacturing processes and quality control practices that have become highly-developed - and proven their worth - in similar industries. These include the recording media, semiconductor, battery and photovoltaic industries [66].

\section{CONCLUSIONS}

The current work has focused on amalgamating the reported findings with respect to design, manufacturing and operational aspects that impact fuel cell performance and longevity, and also on translating these into a hierarchical structure of events in the form of fault tree diagrams. The general conclusions from the current study are as follow;

- A literature review has identified that fuel cells are susceptible to at least twenty-two faults induced by forty-seven general causes.

- The information gathered from literature has been translated into fifty-two basic events and a system of fault trees that reflect how basic events culminate in performance degradation and cell failure.

- The five top events for the system of fault trees are; activation losses, mass transportation losses, Ohmic losses, efficiency losses and catastrophic cell failure.

- In constructing the fault trees, twenty-one reoccurring dominant mechanisms have been identified that hasten performance degradation and cell failure. In the system of FTs these appear as transfer events.

- The most frequent four dominant mechanisms have been traced and discussed in terms of the mitigation mechanisms that can be implemented to curtail their effects on performance degradation and cell failure. These are summarised in Table 3.

\begin{tabular}{|c|c|c|}
\hline Event & $\begin{array}{l}\text { Mitigation } \\
\text { Mechanisms }\end{array}$ & References \\
\hline $\begin{array}{l}\text { The uptake of water } \\
\text { in the ionomer } \\
\text { membrane }\end{array}$ & $\begin{array}{l}\text { - Improving overall } \\
\text { dimensional stability and } \\
\text { mechanical strength of } \\
\text { current membranes } \\
\text { - Dispersion of PTFE } \\
\text { fibrils } \\
\text { - Dispersions of CNT } \\
\text { - Use of ePTFE thin } \\
\text { sheets } \\
\text { - Self-humidifying } \\
\text { membranes } \\
\text { - Dispersions of } \\
\text { silicone oxide- } \\
\text { supported Pt particles } \\
\text { - Developing alternative } \\
\text { polymer systems }\end{array}$ & $\begin{array}{l}{[51]} \\
{[52]} \\
{[53,54,55]} \\
{[54]} \\
{[56]}\end{array}$ \\
\hline $\begin{array}{l}\text { Loss in dynamic } \\
\text { pressure in } \\
\text { channels }\end{array}$ & $\begin{array}{l}\text { - Minimising overall flow- } \\
\text { field path } \\
\text { - Minimising number and } \\
\text { abruptness of flow-field } \\
\text { bends } \\
\text { - Optimising cross- } \\
\text { sectional channel } \\
\text { geometry } \\
\text { - Tapering flow fields } \\
\text { - Matching GDL to BPP } \\
\text { flow field design }\end{array}$ & $\begin{array}{l}58] \\
{[59]} \\
{[67,68,69]} \\
{[70,71]} \\
{[64,65]}\end{array}$ \\
\hline $\begin{array}{l}\text { Liquid water } \\
\text { accumulation }\end{array}$ & $\begin{array}{l}\text { - } \text { Operation at higher } \\
\text { temperatures }\left(>100^{\circ} \mathrm{C}\right) \\
\text { - Use of high-temperature } \\
\text { membranes } \\
\end{array}$ & $\begin{array}{l}{[72,73]} \\
{[74,75,76]}\end{array}$ \\
\hline $\begin{array}{l}\text { Over-compression } \\
\text { during stack } \\
\text { assembly }\end{array}$ & $\begin{array}{l}\text { - Applying manufacturing } \\
\text { practices capable of } \\
\text { repeatability with } \\
\text { accuracy in the context of } \\
\text { exacting dimensions } \\
\text { - Adoption of proven } \\
\text { practices from similar } \\
\text { industries } \\
\text { - Applying statistical quality } \\
\text { control practices to } \\
\text { manage continual } \\
\text { process improvement }\end{array}$ & [77] \\
\hline
\end{tabular}

Table 3: Summary of mitigation mechanisms for common fault-inducing events

From a strategic point of view, the current analysis identifies the following areas of fuel cell research and development that are ultimately critical to enabling fuel cell marketability, and which are strongly related to reliability and performance;

1. Membrane development:

- alleviating the necessity for water retention in the polymer membrane

- improving the mechanical strength and dimensional stability of the polymer membrane

2. BPP development:

- improving the homogeneity of flows through channels and porous media

- establishing BPP materials, material preparation and treatment processes for high mechanical 
strength, high electrical conductivity and low susceptibility to chemical attack

3. Manufacturing and quality control:

- $\quad$ adopting and preparing scalable manufacturing processes and practices from similar established industries

- establishing repeatable precision processes

- adopting quality control practices

It is evidently clear that both novel developments for membrane and BPP materials have to conform with concepts of high-volume and low-cost mass reproducibility from the outset.

The current work has focused on a qualitative assessment of factors that govern fuel cell performance and reliability. Future work will focus on populating the fault tree with reliability data in order to evaluate the statistical significance of failure events and to evaluate the minimal and sufficient conditions needed to induce cell degradation or indeed failure.

\section{REFERENCES}

1. Mehta, V. and J.S. Cooper, Review and analysis of PEM fuel cell design and manufacture. J. Power Sources, 114, 32-53, 2003.

2. Haile, S.M., Fuel cell materials and components Acta. Mater., 51, 5981-6000, 2003.

3. Cooper, J.S., Design analysis of PEMFC bipolar plates considering stack manufacturing and environmental impact. J. Power Sources, 129, 152169, 2004.

4. Andrews, J. D. and T. R. Moss, Reliability and Risk Assessment, Professional Engineering Publishing Limited, Bury St Edmunds, Suffolk, 2002

5. MIL-STD-1629A, Procedures for Performing a Failure Modes Effects and Criticality Analysis, 1998

6. Vesely, W. E., F. F. Goldberg, N. H. Roberts and D. F. Haasl, Fault Tree Handbook, NUREG-0492, US Nuclear Regulatory Commission, 1981

7. Lee, Y.-S., E. Cho, J.-H. Lee, H.-J. Kim, T.-H. Lim, I.$\mathrm{H}$. Oh and J. Won. Effects of purging on the degradation of PEMFCs operating with repetitive on/off cycles. J. Electrochem. Soc. 154(2), B194B200, 2007

8. Merzougui, B. and S. Swathirajan, Rotating Disk Electrode Investigations of Fuel Cell Catalyst Degradation Due to Potential Cycling in Acid Electrolyte. J. Electrochem. Soc. 153(12), A2220A2226, 2006

9. Darling, R. M. and J. P. Meyers, Mathematical Model of Platinum Movement in PEM Fuel Cells. J. Electrochem. Soc. 152(1), A242-A247, 2005

10. Mohtadi, R., W.-K. Lee and J. W. Van Zee, Assessing durability of cathodes exposed to common air impurities. J. Power Sources, 138, 216225, 2004
11. Moore, J. M. , P. L. Adcock PL, J. B. Lakeman and G. O. Mepsted, The effect of battlefield contaminants on PEMFC performance. J. Power Sources, 85, 254260,2000

12. Jing, F., M. Hou, W. Shi, J. Fu, H. Yu, P, Ming and B. $\mathrm{Yi}$, The effect of ambient contamination of PEMFC performance. J. Power Sources, doi:10.1016/j.jpowsour.2006.12.103, 2007

13. Sishtla C., G. Koncar, R. Platon, S. Gamburzev, A. J. Appleby and O. Velev, Performance and endurance of a PEMFC operated with synthetic reformate fuel feed. J. Power Sources 71, 249-255, 1998

14. Qi, Z., C. He and A. Kaufman, Effect of $C O$ in the anode fuel on the performance of PEM fuel cell cathode. J. Power Sources, 111, 239-274, 2002

15. Rama, P., R. Chen, and R. Thring, A polymer electrolyte fuel cell model with multi-species input. Proc. Institute Mech. Engrs. Part A: J. Power and energy, 219, 255-271, 2005

16. SAE Testing Performance of PEM Fuel Cell Stack Sub-system for Automotive Applications. SAE J2617, November 2007, SAE Recommended Practice, 2007

17. Schulze, M., T. Knori, A. Schneider and X. Gülzow, Degradation of sealings for PEFC test cells during fuel cell operation. J. Power Sources 127, 222-229, 2004

18. Cho, E.A., J.-J. Ko, H. Y. Ha, S.-A. Hong, K.-Y. Lee, T.-W. Lim and I.-H. Oh, Characteristics of the PEMFC Repetitively Brought to Temperatures below $0^{\circ} \mathrm{C}$. J. Electrochem. Soc. 150(12), A1667-A1670, 2003

19. Fuller, T. and G. Gray, Carbon Corrosion Induced by Partial Hydrogen Coverage. 208th ECS Meeting, Durability and Reliability of Low-Temperature Fuel Cells Systems, 1(8), 2005

20. Meyers, J. P. and R. M. Darling, Model of Carbon Corrosion in PEM Fuel Cells. J. Electrochem. Soc. 153(8), A1432-A1442, 2006

21. Hwang, J. J., C. H Chao, W. Y. Ho, C. L. Chang and D. Y. Wang, Effect of flow orientation on thermalelectrochemical transports in a PEM fuel cell. J. Power Sources 157, 85-97, 2006

22. Arati, E., M. Pinna and P. Costa, Gas-phase masstransfer resistance at PEMFC electrodes. Part 2. Effects of the flow geometry and the related pressure field. J. Power Sources 158, 206-212, 2006

23. Zhang, F.Y., X. G. Yang and C. Y. Wang, Liquid Water Removal from a Polymer Electrolyte Fuel Cell. J. Electrochem. Soc. 153(2), A225-A232, 2006

24. Yi, J.S. and T. V. Nguyen, Multicomponent Transport in Porous Electrodes of Proton Exchange Membrane Fuel Cells Using the Interdigitated Gas Distributors. J. Electrochem. Soc. 146(1), 38-45, 1999

25. Yan, W.-M., C.-H. Yang, C.-Y. Soong, F. Chen and S.-C. Mei, Experimental studies on optimal operating conditions for different flow field designs of PEM fuel cells. J. Power Sources 160, 284-292, 2006

26. Shyam Prasad, K. B., S. Maharudrayya and S. Jayanti, Flow maldistribution in interdigitated 
channels used in PEM fuel cells. J. Power Sources, 159, 595-604, 2006

27. Hsieh, S.-S., Yang S.-H. Kuo J.-K., Huang C.-F. and Tsai H.-H., Study of operational parameters on the performance of micro PEMFCs with different flow fields. Energy Conversion and Management 2006; 47:1868-1878

28. Lim, C. and C. Y. Wang, Effects of hydrophobic polymer content in GDL on power performance of a PEM fuel cell. Electrochim. Acta 49, 4149-4156, 2004

29. Thoben, B. and A. Siebke, Influence of Different Gas Diffusion Layers on the Water management of the PEFC Cathode. J. New Mater. Electrochem. Syst. 7, 13-20, 2004

30. Yan, Q., H. Toghiani, Y.-W. Lee, K. Liang and H. Causey, Effect of sub-freezing temperatures on a PEM fuel cell performance, startup and fuel cell components. J. Power Sources 160, 1242-1250, 2006

31. Fowler, M.W., R. F. Mann, J. C. Amphlett, B. A. Peppley and P. R. Roberge, Incorporation of voltage degradation into a generalised steady state electrochemical model for a PEM fuel cell. J. Power Sources 106, 274-283, 2002

32. Yin, K-M, Parametric Study of Proton-ExchangeMembrane Fuel Cell Cathode Using an Agglomerate Model. J. Electrochem. Soc. 152(3), A583-A593, 2005

33. Xie, J., F. Garzon, T. Zawodzinski and W. Smith, lonomer Degregation in Composite MEAs and Its Effect on Polymer Electrolyte Fuel Cell Performance. J. Electrochem. Soc. 151(7), A1084-A1093, 2004

34. Mao, L. and C. Y. Wang, Analysis of Cold Start in Polymer Electrolyte Fuel Cells. J. Electrochem. Soc. 154(2), B139-B146, 2007

35. Lee, C. and W. Merida, Gas diffusion layer durability under steady-state and freezing conditions. J. Power Sources 164, 141-153, 2007

36. Ge, J., A. Higier and H. Liu, Effect of gas diffusion layer compression on PEM fuel cell performance. J. Power Sources 159, 922-927, 2006

37. Ihonen, J., M. Mikkola and G. Lindbergh, Flooding of Gas Diffusion Backing in PEFCs. J. Electrochem. Soc. 151(8), A1152-A1161, 2004

38. Nitta, I., T. Hottinen, O. Hilmanen and M. Mikkola, Inhomogeneous compression of PEMFC gas diffusion layer. Part I. Experimental. J. Power Sources doi:10.1016/j.jpowsour.2006.11.018, 2006

39. Davies, D. P., P. L. Adcock, M. Turpin and S. J. Rowen, Stainless steel as a bipolar plate material for solid polymer fuel cells. J. Power Sources, 86, 237242, 2000

40. Cho, E. A., U.-S. Jeon, S.-A. Hong,I.-H. Oh and S.G. Kang, Performance of a $1 \mathrm{~kW}$-class PEMFC stack using TiN-coated 316 stainless steel bipolar plates. J. Power Sources, 142:177-183, 2005

41. Lucio Garcia, M. A. and M. A. Smit, Study of electrodeposited polypyrrole coatings for the corrosion protection of stainless steel bipolar plates for the PEM fuel cell. J. Power Sources, 158, 397402, 2006

42. Springer, T. E., T. A. Zawodzinski and S. Gottesfeld, Polymer Electrolyte Fuel Cell Model. J. Electrochem. Soc., 138, 2334-2342, 1991

43. St-Pierre, J., D. P. Wilkinson, S. Knights and M. Bos, Relationship between water management, contamination and lifetime degradation in PEFC. J. New Mater. Electrochem. Syst. 3, 99-106, 2000

44. Casciola, M., G. Albertu, M. Sganappa and R. Narducci, On the decay of Nafion proton conductivity at high temperature and relative humidity. J. Power Sources, 162, 141-145, 2006

45. Stanic, V., J. Braun and M. Hoberecht, Durability of Membrane Electrode Assemblies (MEAs) in PEM Fuel Cells Operated on Pure Hydrogen and Oxygen. Am. Inst. Aeronautics and Astronautics 21(1), 468475, 2003

46. Hottinen, T., O. Himanen, S. Karbonen and I. Nitta, Inhomogeneous compression of PEMFC gas diffusion layer; Part II. Modeling the effect. J. Power Sources doi:10/1016/j.jopsour.2006.10.076, 2006

47. Curtin, D. E., R. D. Lousenberg, T. J. Henry, P. C. Tangeman and M. E. Tisack, Advanced materials for improved PEMFC performance and life. J. Power Sources 131, 41-48, 2004

48. Kinumoto, T., M. Inaba, Y. Nakayama, K. Ogata, R. Umebayashi, A. Taksaka, Y. Iriyama, T. Abe and Z. Ogumi, Durability of perfluorinated ionomer membrane against hydrogen peroxide. J. Power Sources 158, 1222-1228, 2006

49. Liu, Y.-H., B. Yi, Z.-G. Shao, L. Wang, D. Xing and $H$. Zhang, Pt/CNTs-Nafion reinforced and selfhumidifying composite membrane for PEMFC applications. J. Power Sources 163, 807-813, 2007

50. Weber, A.Z. and J. Newman, Transport in PolymerElectrolyte Membranes; Part II. Mathematical Model. J. Electrochem. Soc. 151(2), A311-A325, 2004.

51. Hommura, S., Y. Kunisa, I. Terada and M. Yoshitake, Characterisation of fibril reinforced membranes for fuel cells. J. Fluorine Chem. 120, 151-155, 2003.

52. Liu, Y.-H., B. Yi, Z.-G. Shao, D. Xing and H. Zhang, Carbon Nanotubes Reinforced Nafion Composite Membrane for Fuel Cell Applications. Electrochem. Solid-State Lett. 9(7), A356-A359, 2006.

53. Ahn, S.-Y., Y.-C. Lee, H. Y. Ha, S.-A. Hong and I.-H. Oh, Properties of the reinforced composite membranes formed by melt soluble ion conducting polymer resins for PEMFCs. Electrochim. Acta 50, 571-575, 2004.

54. Zhang, Y., H. Zhang, X. Zhu, L. Gang, C. Bi and Y. Liang, Fabrication and characterisation of a PTFEreinforced integral composite membrane for selfhumidifying PEMFC. J. Power Sources 165, 786792, 2007.

55. Wang, L., B. L. Yi, H. M. Zhang, Y. H. Liu, D. M. Xing, Z.-G. Shao and Y. H. Cai, Sulfonated polyimide/PTFE reinforced membrane for PEMFCs. J. Power Sources 167, 47-52, 2007. 
56. Hickner, M. A., H. Ghassemi, Y. S. Kim, R. B. Einsla and J. E. McGrath, Alternative Polymer Systems for Proton Exchange Membranes (PEMs). Chem. Rev. 104, 4587-4612, 2004

57. Li, X. and I. Sabir, Review of bipolar plates in PEM fuel cells: Flow-field designs. Int. J. Hydrogen Energy 30, 359-371, 2005.

58. Karvonen, S., T. Hottinen, J. Saarinen and $\mathrm{O}$. Himanen, Modeling of flow field in polymer electrolyte membrane fuel cell. J. Power Sources 161, 876-884, 2006.

59. Shimpalee, S., S. Greenway, J. W. Van Zee, The impact of channel path length on PEMFC flow-field design. J. Power Sources 160, 398-406, 2006.

60. Su, A., F.-B. Weng, C.-Y. Hsu and Y.-M. Chen, Studies on flooding in PEM fuel cell cathode channels. Int. J. Hydrogen Energy 31, 1031-1039, 2006.

61. Trabold, T.A., J. P. Owejan, D. L. Jacobson, M. Arif and P. R. Huffman, In situ investigation of water transport in an operating PEM fuel cell using neutron radiography: Part 1 - Experimental method and serpentine flow field results. Int. J. Heat Mass Transfer 49, 4712-4720, 2006.

62. Trabold, T.A., J. P. Owejan, D. L. Jacobson, M. Arif $M$ and $P$. R. Huffman, In situ investigation of water transport in an operating PEM fuel cell using neutron radiography: Part 2 - Transient water accumulation in an interdigitated cathode flow field. Int. J. Heat Mass Transfer 49, 4721-4731, 2006.

63. Liu, X., H. Guo, F. Ye and C. H. Ma, Water flooding and pressure drop characteristics in flow channels of proton exchange membrane fuel cells. Electrochim. Acta 52, 3607-3614, 2007.

64. Soler, J., E. Hontanon and L. Daza, Electrode permeability and flow-field configuration: influence on the performance of a PEMFC. J. Power Sources 118,172-178, 2003.

65. Dohle, H., R. Jung, N. Kimiaie, J. Mergel and M. Muller, Interaction between the gas diffusion layer and the flow field of polymer electrolyte fuel cells experiments and simulation studies. J. Power Sources, 124,371-384, 2003.

66. U. S. Department of Energy web site, Manufacturing research \& development of PEM fuel cell systems for transportation applications, http://www1.eere.energy.gov/hydrogenandfuelcells/p $\mathrm{dfs} / \mathrm{mfg}$ _wkshp_fuelcell.pdf

67. Shyam Prasad, K. B., S. Maharudrayya and S. Jayanti, Flow maldistributioin in interdigitated channels used in PEM fuel cells. J. Power Sources 159, 595-604, 2006

68. Shimpalee, S. and J. W. Van Zee, Numerical studies on rib \& channel dimension of flow-field on PEMFC performance. Int. J. Hydrogen Energy 32, 842-856, 2007

69. Yoon, Y.-G., W.-Y. Lee, G.-G. Park, T.-H. Yang and C.-S. Kim, Effects of channel configuration of flow field plates on the performance of a PEMFC. Electrochim. Acta 50, 709-712, 2004
70. Liu, H. C., W. M. Yan, C. Y. Soong, F. Chen and H. S. Chu, Reactant gas transport and cell performance of proton exchange membrane fuel cells with tapered flow field design. J. Power Sources 158, 7887, 2006

71. Chiang, M. S., H. S. Chu, C. K. Chen and S. R. Jian, Electrochemical reaction and performance of proton exchange membrane fuel cells with a novel cathode flow channel shape. J. Power Sources 166, 362-375, 2007

72. Mallant, R. K. A. M., PEMFC systems: the need for high temperature polymers as a consequence of PEMFC water and heat management. J. Power Sources 118, 424-429, 2003

73. Coppo, M., N. P. Siegle and M. R. von Sparkovsky, On the influence of temperature on PEM fuel cell operation. J. Power Sources 159, 560-569, 2006

74. Song, Y., H. Xu, Y. Wei, R. Kunz, L. J. Bonville and J. M. Fenton, Dependance of high-temperature PEM fuel cell performance on Nafion content. J. Power Sources 150, 738-144, 2006

75. Shao, Y., G. Yin, Z. Wang and Y. Gao, Proton exchange membrane fuel cell from low temperature to high temperature: Material challenges. J. Power Sources, 167, 235-242, 2007

76. Li, Q., R. He, J. O. Jensen and N. J. Bjerrum, PBIBased Polymer Membranes for High Temperature Fuel Cells - Preparation, Characterization and Fuel Cell Demonstration, Fuel Cells 4(3), 147-159, 2004

77. Evans, J. R. and W. M. Lindsay, The Management and Control of Quality, South-Western, Mason, Ohio, 2005

\section{CONTACT}

Pratap Rama

The Department of Aeronautical and Automotive

Engineering

Loughborough University

Leicestershire

LE11 3TU

United Kingdom

Email:p.rama@lboro.ac.uk

\section{APPENDIX}

\section{BASIC DESCRIPTION EVENT}

\begin{tabular}{|ll|}
\hline Electronic Load Control \\
ELC1 & Stack operating current $>0 \mathrm{~A}$ \\
ELC2 & High operating stack current density \\
ELC3 & Cold start \\
ELC4 & Repetitive load cycling \\
ELC5 & $\begin{array}{l}\text { Cell operated through } \mathrm{H}_{2} \text {-air open circuit to air-air } \\
\text { open circuit }\end{array}$ \\
& \\
\hline Humidity Control \\
HC1 & Relative humidity of reactant supply approaching \\
HC2 & unity (RH $\leq 1)$ \\
HC3 & Humidification of fuel supply to anode \\
& Humidification of oxidant supply to cathode \\
\hline
\end{tabular}




\begin{tabular}{|c|c|}
\hline \multicolumn{2}{|c|}{ Mechanical Components } \\
\hline AC1 & Air compressor blockage \\
\hline AC2 & Mechanical failure of air compressor \\
\hline CP1 & Mechanical failure of coolant pump \\
\hline HS1 & $\begin{array}{l}\text { Impurity ions released from FC hardware and } \\
\text { system piping upstream of stack }\end{array}$ \\
\hline GDL1 & Irregularity in GDL carbon fibre structure \\
\hline S1 & Chemical degradation of silicone seals \\
\hline \multicolumn{2}{|c|}{ Thermal Management System } \\
\hline TMS1 & $\begin{array}{l}\text { Coolant flow rate set too low by thermal } \\
\text { management system }\end{array}$ \\
\hline TMS2 & Repeated thermal cycling \\
\hline \multicolumn{2}{|c|}{ Bipolar Plate } \\
\hline BPP1 & Fine channel geometry of BPP design \\
\hline BPP2 & High number of flow-field bends in BPP design \\
\hline BPP3 & Warping of injection-molded BPP \\
\hline BPP4 & Low thermal conductivity of designed BPP \\
\hline BPP5 & $\begin{array}{l}\text { Corrosion of stainless steel BPP under acidic and } \\
\text { high humidity FC conditions }\end{array}$ \\
\hline BPP6 & $\begin{array}{l}\text { Formation of passivating layer on stainless steel } \\
\text { BPP surface }\end{array}$ \\
\hline BPP7 & $\begin{array}{l}\text { Degradation of conductive polymer coating of coated } \\
\text { stainless steel BPP }\end{array}$ \\
\hline BPP8 & $\begin{array}{l}\text { Formation of micro-cracks on TiN coated stainless } \\
\text { steel BPP }\end{array}$ \\
\hline BPP9 & $\begin{array}{l}\text { Inhomogeneous mixing of polymer matrix and } \\
\text { conductive filler for polymeric injection-molded BPP }\end{array}$ \\
\hline \multicolumn{2}{|c|}{ Fuel Supply (to anode) } \\
\hline FS1 & Low flow rate set for fuel supply to anode \\
\hline FS2 & Un-purged shut-down of anode side \\
\hline FS3 & Low pressure set for fuel supply to anode \\
\hline FS4 & Crossover of impurities in the fuel supply \\
\hline FS5 & Impurities in the fuel supply to anode \\
\hline FS6 & Crossover of fuel to cathode side \\
\hline FS7 & Fuel supply to anode \\
\hline FS8 & High flow rate of fuel supply to anode \\
\hline \multicolumn{2}{|c|}{ Oxidant Supply (to cathode) } \\
\hline OS1 & Low flow rate set for oxidant supply to cathode \\
\hline OS2 & Un-purged shut-down of cathode side \\
\hline OS3 & High pressure set for fuel supply to cathode \\
\hline OS4 & Crossover of impurities in the oxygen supply \\
\hline OS5 & Crossover of oxygen to anode side \\
\hline OS6 & Air bleed to anode side \\
\hline OS7 & Oxidant supply to cathode \\
\hline \multicolumn{2}{|c|}{ Stack Assembly } \\
\hline SA1 & Over-compression during stack assembly \\
\hline SA2 & Inhomogeneous compaction during stack assembly \\
\hline \multicolumn{2}{|c|}{ Environmental Effects } \\
\hline E1 & $\begin{array}{l}\text { Sudden mechanical shock transmitted to FC } \\
\text { powerplant via chassis }\end{array}$ \\
\hline E2 & Vibration transmitted to FC powerplant via chassis \\
\hline E3 & Sub-zero operating environment \\
\hline E4 & $\begin{array}{l}\text { Atmospheric impurity ions in the oxidant supply to } \\
\text { cathode (charged) }\end{array}$ \\
\hline E5 & $\begin{array}{l}\text { Atmospheric impurities in the oxidant supply to } \\
\text { cathode (zero valence) }\end{array}$ \\
\hline \multicolumn{2}{|r|}{ 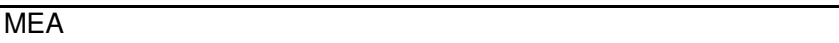 } \\
\hline MEA1 & Defects during membrane polymerisation process \\
\hline MEA2 & $\begin{array}{l}\text { Excessive ionomer loading in catalyst layer during } \\
\text { MEA manufacture }\end{array}$ \\
\hline MEA3 & $\begin{array}{l}\text { Formation of ionomer skins on catalyst layers during } \\
\text { the standard decal/hot-press transfer method }\end{array}$ \\
\hline MEA4 & Available EASA of platinum catalyst \\
\hline MEA5 & $\begin{array}{l}\text { Short circuit due to platinum network in self- } \\
\text { humidifying membranes }\end{array}$ \\
\hline
\end{tabular}

